\title{
PREDIX: A New Tool for Measuring Disaster Resilience Index Performance of Community Health Center
}

\author{
Rina Suryani Oktari ${ }^{\#, *}$, Safrizal Rahman*, Tita Menawati Liansyah*, Nasliati ${ }^{\$}$ \\ \# Tsunami \& Disaster Mitigation Research Center (TDMRC), Universitas Syiah Kuala, Banda Aceh, 23111, Indonesia \\ E-mail:okta@unsyiah.ac.id \\ *Faculty of Medicine, Universitas Syiah Kuala, Banda Aceh, 23111, Indonesia \\ E-mail:safrizalrahman@unsyiah.ac.id,titamenawati@unsyiah.ac.id \\ ${ }^{\$}$ Faculty of Computer Science, Universitas Bung Karno, Jakarta Pusat, 10310, Indonesia \\ E-mail: lia.albanna@gmail.com
}

\begin{abstract}
A Puskesmas is the singular Indonesian term for a Community Health Center, hereinafter termed as a Puskesmas Community Health Center or simply a PCHC. A PCHC operates under government directives at the sub-district level in Indonesia. A PCHC provides extensive services for the development of health and bolsters such health endeavors at the public-level and at the individual-level. A PCHC is a critical protagonist in reducing the problems created by a disasters hence the concept of the resilience of the PCHC in the face of disaster needs to be promoted. The aim of the present study was to design a Dashboard Screen Toolkit (DST) for performance monitoring and evaluation based on a canvas of PCHC resilience. The authors have developed a "PCHC' Resilience to Disasters Index (PREDIX)" which is a computer interface or dashboard for visualizing PCHC resilience indicators. This means that disaster prevention personnel can monitor of PCHC resilience index performance data using a transparent and easy-tooperate medium. The stages of creating a DST for PREDIX has these steps: identifying parameters and indicators/indices of the PCHC resilience; evidence of design feasibility; building the technology connectivity roadmap for hosting the DST; catering for multiple platforms, and creating pertinent systems as a basis for the incorporation of fine-scale data. A conceptual model was built for documenting the components of the measurement process of the disaster resilience of a PCHC, incorporating potential measures for the production of a real-time evaluation tool-kit. The model has five parameters for measuring the disaster resilience of a PCHC, which are: real-time conditions of structures, institutional issues, the work force and personnel, external networks, and exposure to disaster. The PREDIX DST, hereinafter termed as PDST gives a visual interface to channel bulk information onto an interface monitor. The PDST complements strategic decision making with the goal of increasing the disaster resilience of a PCHC. The PDST provides charts that display structural and non-structural resilience measurements of PCHC. The PDST can also become enabled for the Internet. This innovative tool kit will help to tracking the progress of the disaster resilience of a PCHC. The PDST will aid policy makers regarding any necessary increase in PCHC resilience to disasters.
\end{abstract}

Keywords - disaster; resilience; Puskesmas Community Health Center; Indonesia; healthcare; dashboard screens tool kit.

\section{INTRODUCTION}

Innumerable individuals worldwide have their lives disrupted by natural and man-made disasters on a nearannual basis and the impact on the society is devastating with both direct and indirect impacts on population health and also on the health care system. Injuries and deaths are the most evident of impacts of natural disasters on population health. In year 2016 there were 342 natural disasters, causing 564.4 million individuals to be affected and there were over 110 million victims with close to USD 154 billion of damage to various economies [1].
Disasters guarantee multi-dimensional impacts in $100 \%$ of cases and one of the most affected sectors is health. Impacts can include the shutdown of health services, environmental sanitation services and reproductive health services, plus an increase in the mortality rate, injuries, refugees, nutritional problems, water health problems, communicable diseases, and ensuing psychiatric disorders. The damage that is created by the disaster will affect all parts of the society including the health care system which is more prone to disruptions via disasters [2], [3], [4], [5].

The Sendai Framework for Disaster Risk Reduction (SFDRR, 2015-2030) underlines health systems that are resilient by incorporating disaster risk management into 
healthcare facilities and infrastructures on a multilevel basis, and by 1) training health personnel in disaster risk assessment and 2) the emplacement of disaster risk strategies within the health care system. The aim is to attenuate mortality, increasing population wellbeing, early warning and promoting the ongoing validity/safety of health care facilities [6], [7], [8], [9].

This paper discusses the design of a dashboard screen system that enables performance monitoring and evaluation within the frame of PCHC resilience. We developed the PCHC Resilience to Disasters Index (PREDIX) as a DST in order to visualize the resilience indicators of the PCHC that are designed to enable the observation of resilience index performance data in a transparent and in an easy-to-use manner.

\section{MATERIALs AND METHODs}

The stages in the creation of a DST for PREDIX are: 1) identifying parameters and indicators/indices of the PCHC resilience; 2) evidence of design feasibility; 3) building the technology connectivity roadmap for hosting the DST; 4) catering for multiple platforms, and 5) creating pertinent systems as a basis for the incorporation of fine-scale data.

A conceptual model was fabricated for logging the components of the measurement process of the disaster resilience of a $\mathrm{PCHC}$, with potential measures for producing a real-time evaluation tool-kit.

\section{RESULT AND DISCUSSION}

\section{A. General Framework of Disaster Resilience of a PCHC}

Figure 1 presents the PCHCs at the sub-district level. In Indonesia, PCHCs offer the fundamental level of health care, modern services and ongoing promotion public health services. There are 6fundamental services: 1) proper control over health, 2) environmental health, 3) health in pregnancy and infant health, 4) improvement in nutrition for the general population, 5) prevention and eradication of infectious diseases, and 6) disease eradication. The PCHCs play an important role in the Indonesian health system and they must respond to the health needs of the population in a preventative and adaptive manner, as well as providing punctual and affordable health services [10].

When a disaster strikes, there can be a considerable reduction in the impact on health when the authorities and the communities in high-risk areas are well prepared. The outcome is a reduction in their vulnerabilities and an enhancement of their resilience to disaster [11]. Health facilities, such as PCHC, must stay functional during any disaster events. Critical care is usually compromised, and the mortality rate will increase needlessly when the relevant health facilities do not have the capacity to fulfill their emergency response function during a period of dire need [12].

The PCHC is run by the state and it will play a critical role in containing the damage to health impact when a disaster strikes. Hence, PCHC resilience must be a key factor. Oktari \& Kurniawan [13] developed a general framework for the resilience of a PCHC to any adverse event of great magnitude using these variables: 1) real-time physical conditions of structures, 2) institutional issues, 3) personnel or work force, 4) external human networkss, and 5) disaster exposure [13]. Figure 2 shows the hierarchy of the PCHC Disaster Resilience Indexes.

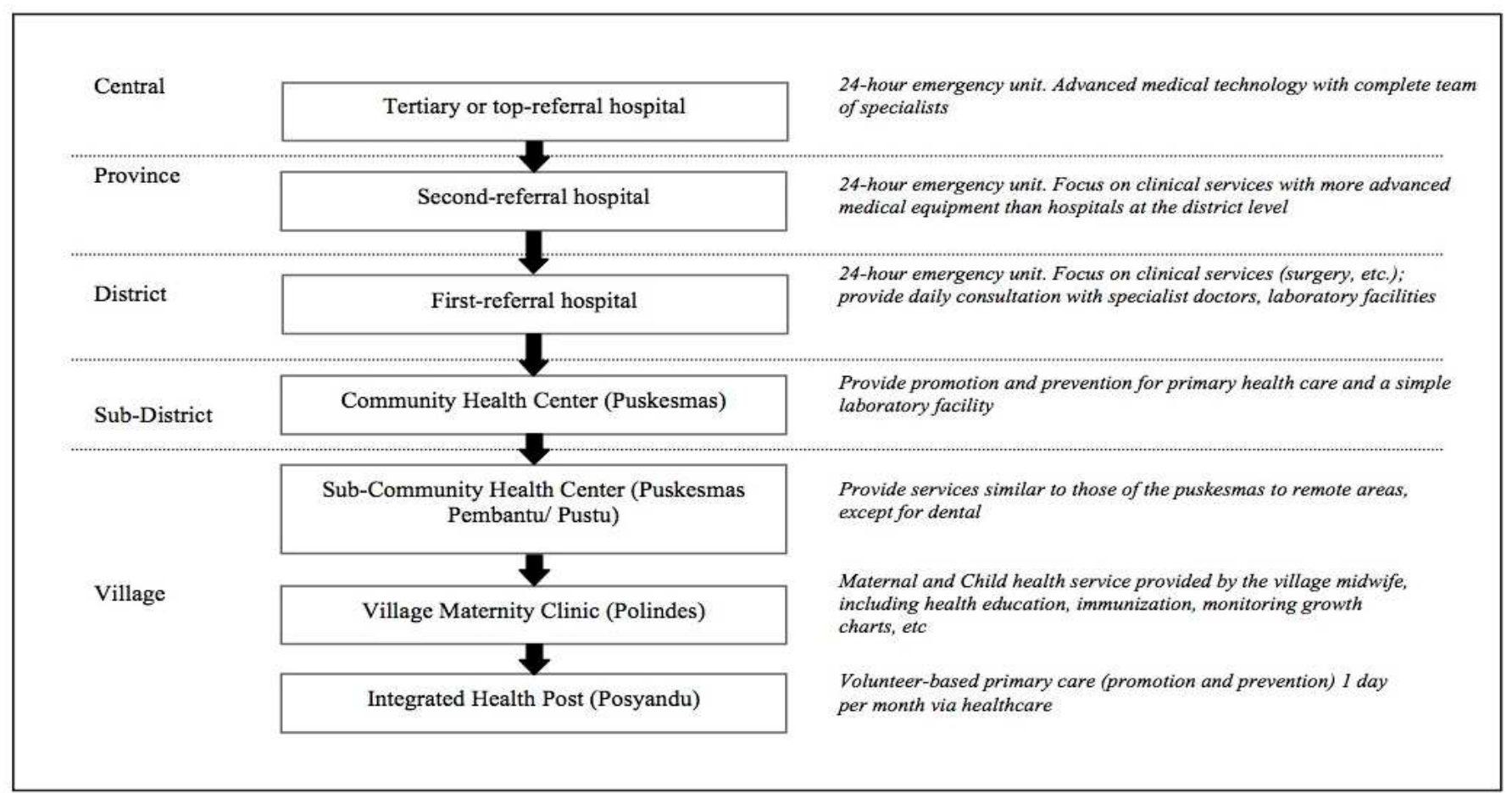

Fig. 1 Indonesian health facilities at various levels 


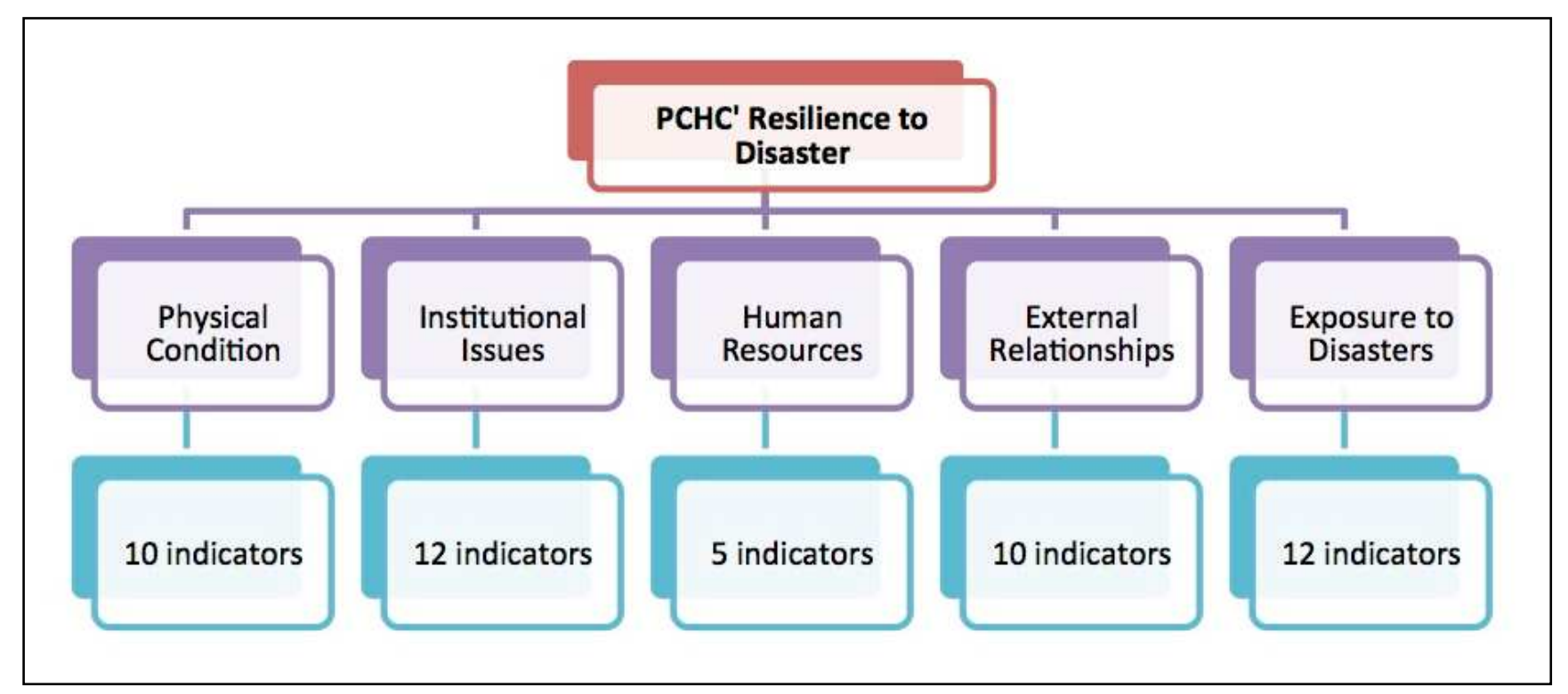

Fig. 2 Hierarchy of PCHC' resilience indicators

Variable one: physical condition. PCHCs are the civil militias in a first-line-of-defense of public health services and they play a crucial role when a disaster strikes. It is essential for the PCHC to be of solid and resistant construction in order to perform crucial post-disaster functions, hence these factors must be documented: 1) road map to and from the PCHC for air and land rescue transport, 2) ease of to the PCHC, 3) the structure of the PCHC, 4) the available amenities at the $\mathrm{PCHC}$, and 5) available and usable equipment at the PCHC [13].

Variable two: institutional issues. The priority for the primary activity mentioned in the Hyogo Framework for Action (HFA, 2005-2015), is to assure that there will be a Disaster Risk Reduction (DRR) with a strong and viable institutional substrate. Thus, implementing the priority of the action requires mechanisms for reinforcing institutional issues related to the DRR, which must be integrated into 1) planning, 2) the reviewing of human and financial needs, and 3) the allocation of other necessary resources [14]. Regarding specifically $\mathrm{PCHC}$, institutional resilience requires assessment of the variables of 1) planning, 2) management, and 3) budget allocation [15].

Variable three: Personnel and work force. This variable assesses the main factors making up work force that will be equipped for any upcoming disaster, including medics, paramedics, nurses, auxiliaries, midwives, and health workers and any admin staff who are responsible for the operation of the PCHC. In addition, this variable also assesses the organization of the personnel that make up the Disaster Management Committee and the emergency operations center of the PCHC [16].

Variable four: external relations. Should a disaster strike, then the management of relationships with non-PCHC actors on the outside plays a crucial part in handling any reaction to a disaster emergency. This variable calculates:- 1) the human and infrastructure interface between the PCHC and the ordinary people at risk, 2) collaboration with external actors, and 3) the level of support provided by the mobilization of funds from the actors. This variable will note the efforts of the PCHC in giving disaster education to communities and showing them how to react when disasters strike and how to be involved in the emergency operations of a PCHC. Further, a collaborative assessment of stakeholders is also undertaken and this will ensure fully operational coordination and communication infrastructures with actors/stakeholders. Fund mobilization assessments have already been undertaken to make certain that there would be governmentfunded support, the private sector support, non-government agency (NGO) support, and other institutional support [17], [18].

Variable five: exposure to disaster. This variable examines disaster frequency and disaster severity, and also the environmental conditions where the PCHC are situated. This observation includes 1) the frequency of occurrence of geological threats, 2) hydro-meteorological threats, 3) different problems, and 3) the impact of such threats and problems on the PCHC. Further, the assessment of the surrounding environment is undertaken utilizing a risk assessment of 1) related threats/hazards, and 2) the distance from a health center to the coast, to a mountain or hill, to a hospital, to a law enforcement station, and to a government office [17], [18].

To measure the level of resilience of a PCHC when disaster strikes, the five parameters described in the above, are used as indicators (see Figure 3).

\section{B. Dashboard screen as a Decision Support System (DSS)}

A dashboard screen is a visual and interactive tool enabling performance management, whereby the most significant information that is required to reach the goals of individuals and organizations is presented on a single monitor. This will then permit the end-user to identify, explore, and communicate problem areas that require corrective action [19]. As a particular type of DSS, the DST will integrate visual and functional features, and the combined effects aid in the enhancement of cognition and interpretation [19], [20]. 
The DST technology draws on Information Systems Theory (IST), Cognitive Psychology Theory (CST), and Accounting Theory. Complex data are communicated to the decision maker via a visualization process (representations of data that are abstract and non-physically based) in order to augment end-user cognition [21].

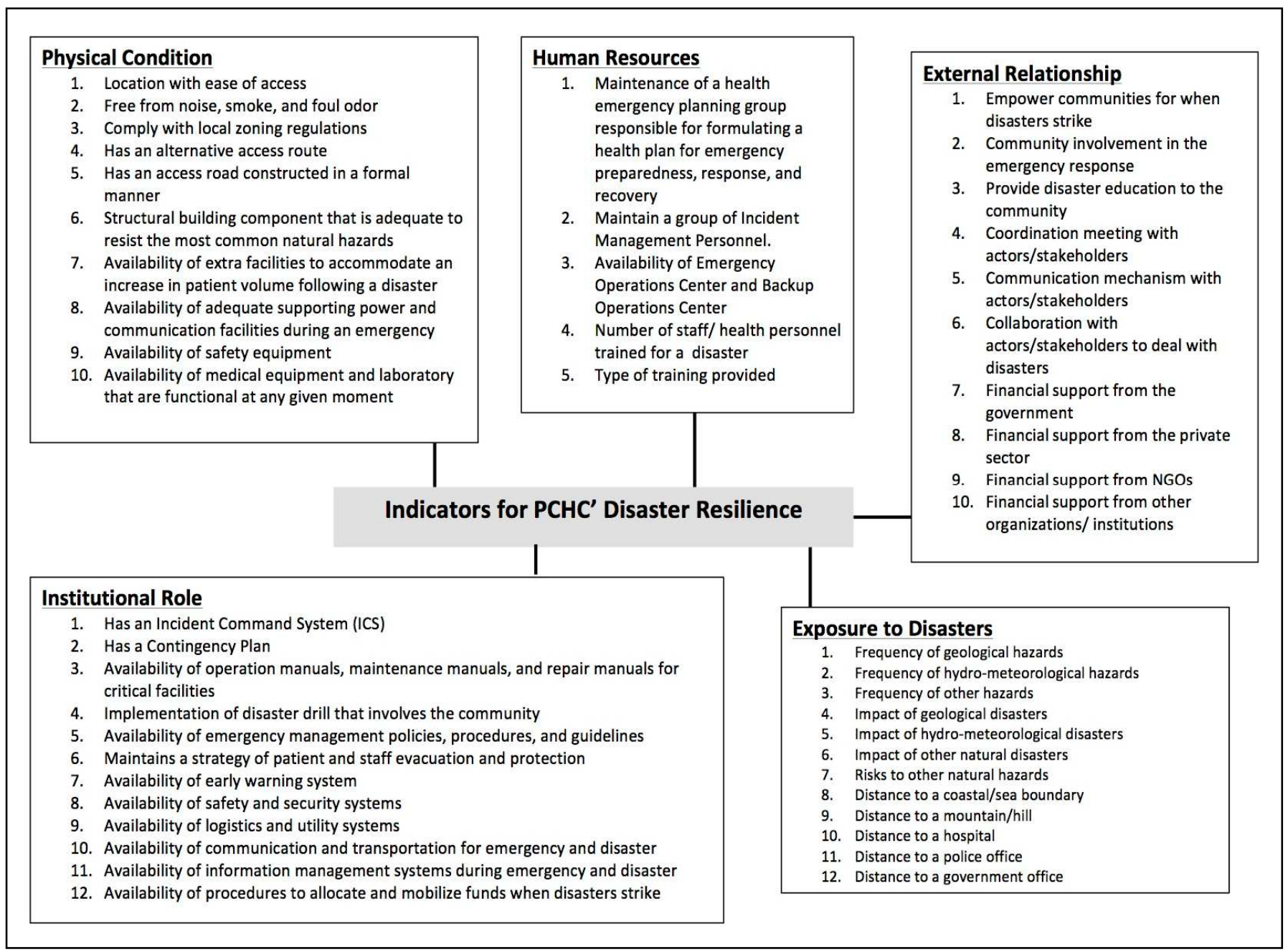

Fig. 3 PCHC’ Disaster Resilience Indicators [2, 13, 17]

Dashboard screens permit various information appearances of performance metrics at various levels of aggregation utilizing a dynamic content user communication. In this way, there are 1) graphs for high level comparison of indicator performance and 2) the possibility of further analysis of detailed data (these data are likely to be presented as tables). Hence, dashboard screens can be utilized for tasks that both spatial and symbolic. The most recent generations of dashboard screens provide future potential (or "what-if") scenarios for deciding an action course that would potentially lead to the most desired result. The dynamism of the displayed information on dashboard screens is novel [22].

In the body of literature, there is a literature review on investigations of alternative methodologies, whereby information systems may influence decision making, such as: 1) decision support systems, 2) effects of information aggregation and information load, and 3) system competence in giving interaction and feedback [23]. Dashboard screens often utilize color to discriminate among different objects or to understand and classify different objects [24]. The information displayed on the dashboard screen should provide a gateway to supplementary information, although it is especially advisable that a dashboard screen should fit onto a single computer screen [25]. Hence, the latest generation of dashboard screens need point-and-click interactivity which enables users to move information from one place to another in order to obtain more extensive information on a variety of performance measures. Also, dashboard screens can assist users in identifying measures that require immediate attention, by alerting the user in a visual manner when the performance indicators become out of range.

Dashboard screens have recently become favored by governments in open government efforts to augment transparency and to get citizens and businesses interested. This should bring extra efficiency and should also promote the population's trust of the government [25], [26].

Dashboard screens are not solely about the technology they use because they promote how data science research results will be utilized [27]. Even if a dashboard screen is designed in a proper manner from a technical perspective, fraud detection or identification of strange or anomalous patterns usually occurs when there is no mechanism of 
inherent coaxing or cajoling and technical involvement by scientists to explore these patterns more exhaustively [28].

\section{The concept of the DST for PCHC Resilience to Disasters Index}

In Figure 4, the design process of PREDIX dashboard is described. We engineered the DST as a visual interface which funnels bulk data and bulk information onto an interface screen which aids in decision making related to strategy to effectively augment the resilience of a $\mathrm{PCHC}$ to disasters.

This PREDIX DST will furnish charts displaying PCHC resilience in both structural and non-structural measurement. The PREDIX DST paves the way for an Internet connectivity to provide more that the existing information. This new tool will assist in 1) real-time monitoring of the resilience of a PCHC, 2) surveillance and reportage, and 3) informing policy makers on augmenting resilience toward disaster. PREDIX DST technology is outlined in Figures 5, 6 and 7, respectively.

The PREDIX DST (as a graphical user interface), conveys data and knowledge on the resilience of a PCHC to disasters utilizing Information Visualization. The PREDIX dashboard follows a Good Design Principles such as maximizing the data-ink ratio and minimizing the excessive use of color.

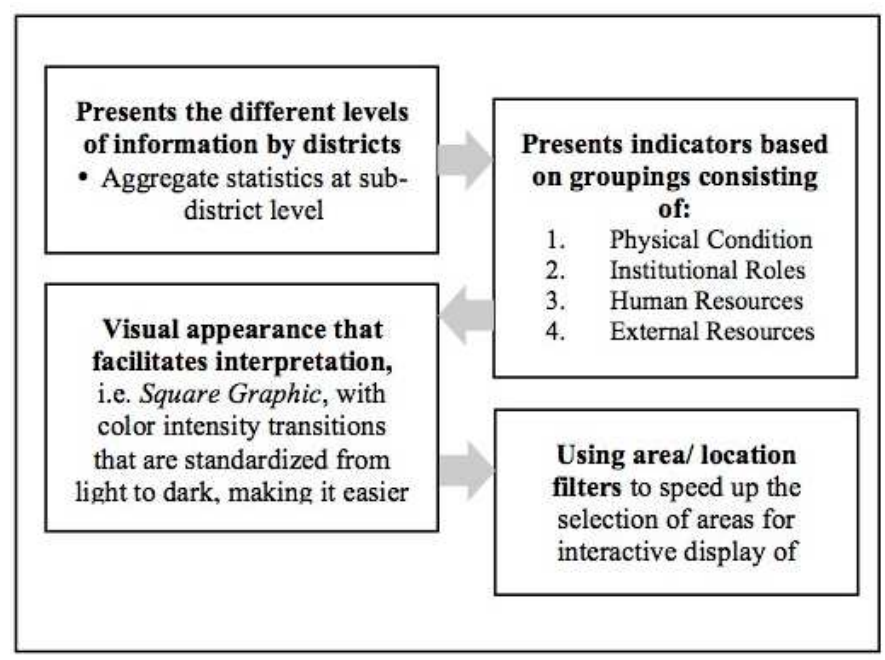

Fig. 4 Dashboard design process for PREDIX

The PREDIX DST, as aforementioned, is derived of the unmet need for more resilience of PCHCs to disasters. A PREDIX DST is a data visualization tool that is designed to provide the end-user with a quick-look examination that communicates the structural and non-structural aspects of the overall status of the resilience of the PCHCs to disasters .

\begin{tabular}{|c|c|c|c|c|c|}
\hline \multicolumn{6}{|c|}{ INSTITUTIONAL RESILIENCE } \\
\hline \multicolumn{3}{|c|}{ The availability of health workers trained in face disasters } & \multicolumn{3}{|c|}{ The existence of personnel responsible in the system command emergency incident } \\
\hline Kecamatan & Puskesmas & & Kecamatan & Puskesmas & \\
\hline Baiturrahman & Baiturrahman & $\checkmark$ & Baiturrahman & Baiturrahman & $\mathrm{X}$ \\
\hline Banda Raya & Banda Raya & $\checkmark$ & Banda Raya & Banda Raya & X \\
\hline Jaya Baru & Jaya Baru & $\mathrm{X}$ & Jaya Baru & Jaya Baru & $\mathrm{X}$ \\
\hline Kuta Alam & Lampulo & X & Kuta Alam & Lampulo & $\mathrm{X}$ \\
\hline Kuta Raja & Lampaseh & $\mathrm{X}$ & Kuta Raja & Lampaseh & $\mathrm{X}$ \\
\hline Lueng Bata & Batoh & X & Lueng Bata & Batoh & X \\
\hline Meuraxa & Meuraxa & $\mathrm{X}$ & Meuraxa & Meuraxa & $X$ \\
\hline Syiah Kuala & Jeulingke & X & Syiah Kuala & Jeulingke & $\checkmark$ \\
\hline Ulee Kareeng & Ulee Kareeng & $\mathrm{X}$ & Ulee Kareeng & Ulee Kareeng & $\mathrm{X}$ \\
\hline \multicolumn{3}{|c|}{$\begin{array}{c}\text { The existence of personnel responsible for a center of operations and } \\
\text { a center of operations a substitute in emergencies }\end{array}$} & \multicolumn{3}{|c|}{$\begin{array}{l}\text { The existence of groups health planner emergency } \\
\text { plan responsible formulate preparedness, responses and disaster recovery }\end{array}$} \\
\hline Kecamatan & Puskesmas & & Kecamatan & Puskesmas & \\
\hline Baiturrahman & Baiturrahman & $x$ & Baiturrahman & Baiturrahman & $x$ \\
\hline Banda Raya & Banda Raya & X & Banda Raya & Banda Raya & $\mathrm{X}$ \\
\hline Jaya Baru & Jaya Baru & $x$ & Jaya Baru & Jaya Baru & $x$ \\
\hline Kuta Alam & Lampulo & X & Kuta Alam & Lampulo & $\mathrm{X}$ \\
\hline Kuta Raja & Lampaseh & $X$ & Kuta Raja & Lampaseh & $X$ \\
\hline Lueng Bata & Batoh & X & Lueng Bata & Batoh & $x$ \\
\hline Meuraxa & Meuraxa & $x$ & Meuraxa & Meuraxa & $x$ \\
\hline Syiah Kuala & Jeulingke & $x$ & Syiah Kuala & Jeulingke & $\checkmark$ \\
\hline Ulee Kareeng & Ulee Kareeng & 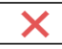 & Ulee Kareeng & Ulee Kareeng & $x$ \\
\hline
\end{tabular}

Fig. 5 Example of institutional resilience assessment by sub-district 
The availability of energy facilities reserve and communication when emergency

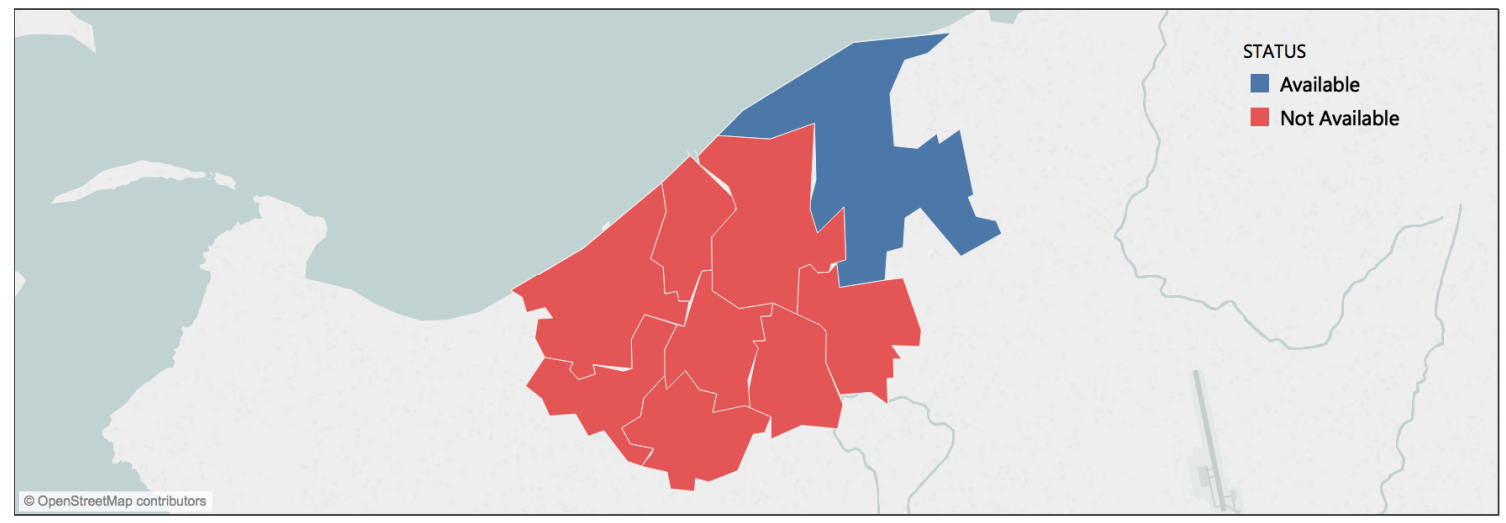

The existence of personnel responsible in the system command emergency incident

\begin{tabular}{|l|l|c|}
\hline Kecamatan & Puskesmas & \\
\hline Baiturrahman & Baiturrahman & $\checkmark$ \\
\hline Banda Raya & Banda Raya & $\checkmark$ \\
\hline Jaya Baru & Jaya Baru & $\times$ \\
\hline Kuta Alam & Lampulo & $\times$ \\
\hline Kuta Raja & Lampaseh & $\mathrm{X}$ \\
\hline Lueng Bata & Batoh & $\mathrm{X}$ \\
\hline Meuraxa & Meuraxa & $\mathrm{X}$ \\
\hline Syiah Kuala & Jeulingke & $\mathrm{X}$ \\
\hline Ulee Kareeng & Ulee Kareeng \\
\hline
\end{tabular}

\begin{tabular}{|l|l|c|}
\hline Kecamatan & Puskesmas & \\
\hline Baiturrahman & Baiturrahman & $\mathbf{X}$ \\
\hline Banda Raya & Banda Raya & $\mathbf{X}$ \\
\hline Jaya Baru & Jaya Baru & $\mathbf{X}$ \\
\hline Kuta Alam & Lampulo & $\mathbf{X}$ \\
\hline Kuta Raja & Lampaseh & $\mathbf{X}$ \\
\hline Lueng Bata & Batoh & $\times$ \\
\hline Meuraxa & Meuraxa & $\checkmark$ \\
\hline Syiah Kuala & Jeulingke & $\times$ \\
\hline Ulee Kareeng & Ulee Kareeng & \\
\hline
\end{tabular}

Fig. 6 Example PREDIX' dashboard of indicator by sub district

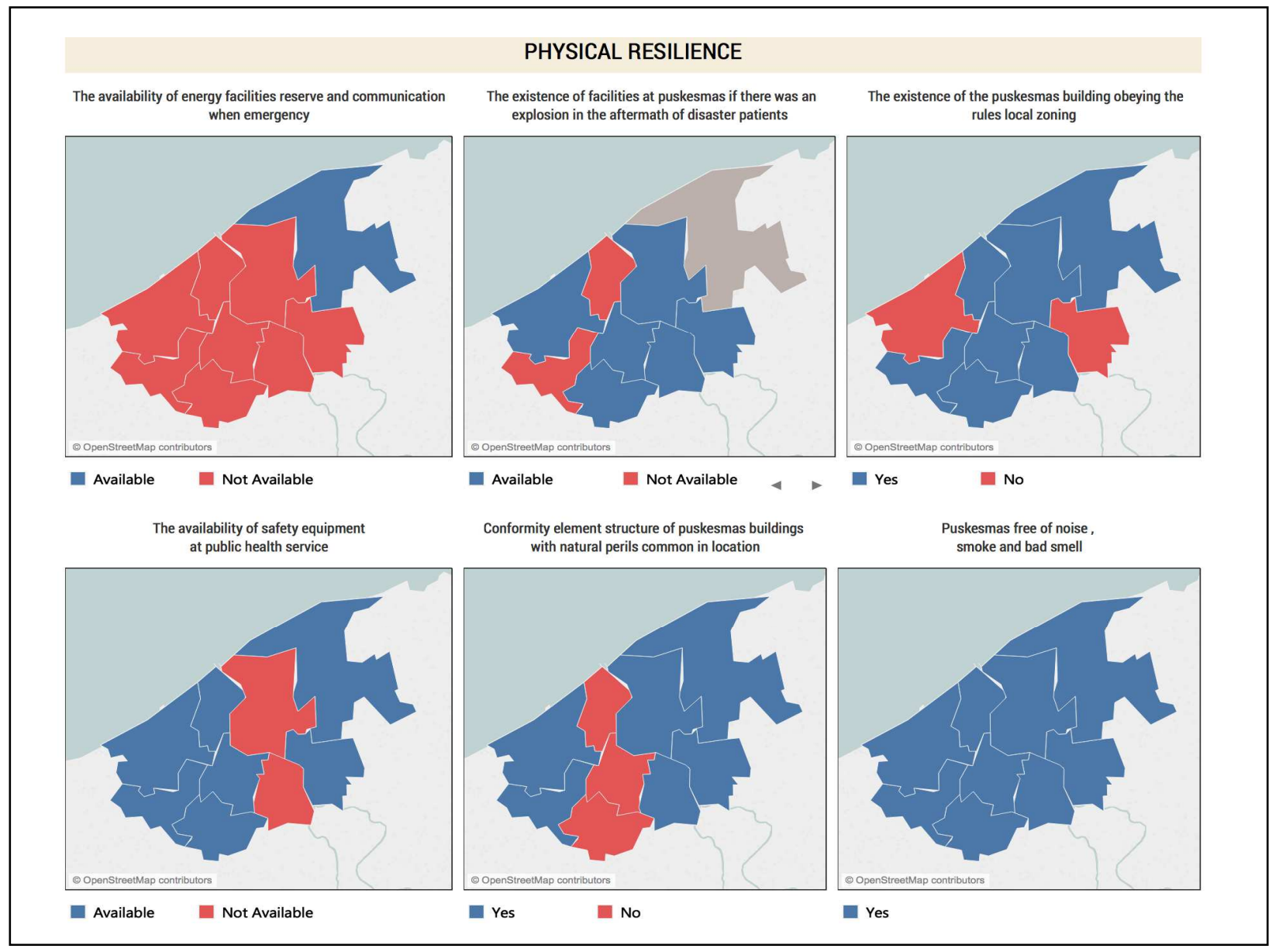

Fig. 7 Example results on the physical resilience indicator of PREDIX' dashboard 


\section{IV.CONCLUSIONS}

The goal of this research was to come up with a viable DST for observing, checking and evaluating the resilience to disasters of PHCCs. The PREDIX DST is a visual interface that funnels big-sized data and information into a presentable format. The process enhances decision making with the aim of augmenting the resilience to disaster of PHCCs. This PREDIX DST gives out easy-to-read graphs that indicate structural surveys and non-structural surveys of the resilience of PHCCs. It paves the way for an Internetenabled, interactive resilience index DST. This new tool will assist in tracking improvement of the resilience, monitoring, and reporting of PHCCs to augment their resilience to disaster.

\section{ACKNOWLEDGMENT}

Thanks go to all colleagues who lent a hand in this research. The research is funded by Universitas Syiah Kuala and KEMRISTEKDIKTI (Agreement Number 291/UN11/SP/PNBP/2018).

\section{REFERENCES}

[1] D. Guha-Sapir, Ph. Hoyois, and R. Below, "Annual Disaster Statistical Review 2016: The Numbers and Trends," Brussels: CRED, 2017.

[2] Pan American Health Organization Health Sector Self-Assessment Tool for Disaster Risk Reduction. Washington, DC, 2010.

[3] R. Berariu, C. Fikar, M. Gronalt, and P. Hirsch, "Understanding the impact of cascade effects of natural disasters on disaster relief operations," International Journal of Disaster Risk Reduction, vol. 12, pp. 350-356, 2015.

[4] A.M. Chand, and M. Loosemore, "Hospital disaster management's understanding of built environment impacts on healthcare services during extreme weather events," Engineering, Construction and Architectural Management, vol. 23(3), pp.385-402, 2016.

[5] M. L. Birnbaum, E. K. Daily, A. P. O'Rourke, and A. Loretti, "Research and evaluations of the health aspects of disasters, Part II: the disaster health conceptual framework revisited," Prehospital and disaster medicine, vol. 30(5), pp. 523-538, 2015.

[6] UNISDR. Sendai framework for disaster risk reduction 2015-2030. Geneva: UNISDR, 2015.

[7] A. Aitsi-Selmi, S. Egawa, H. Sasaki, C. Wannous, and V. Murray, "The Sendai framework for disaster risk reduction: Renewing the global commitment to people's resilience, health, and well-being," International Journal of Disaster Risk Science, vol. 6(2), pp. 164-176, 2015.

[8] A. Aitsi-Selmi and V. Murray, "Protecting the health and well-being of populations from disasters: Health and health care in the Sendai framework for disaster risk reduction 2015-2030," Prehospital and disaster medicine, vol. 31(1), pp. 74-78, 2016.

[9] L. Reifels, P. Arbon, A. Capon, J. Handmer, A. Humphrey, V. Murray, and C. Spencer, "Health and disaster risk reduction regarding the Sendai Framework," Australian Journal of Emergency Management, vol. 33(1), pp. 23-24, 2018.

[10] Regulation of the Minister of Health of the Republic of Indonesia Number 75 Year 2014 on Community Health Center (Puskesmas).
[11] World Health Organization. Risk reduction and emergency preparedness: WHO six-year strategy for the health sector and community capacity development, 2007.

[12] F. Mulyasari, S. Inoue, S. Prashar, K. Isayama, M. Basu, N. Srivastava, and R. Shaw, "Disaster preparedness: Looking through the lens of hospitals in Japan," International Journal of Disaster Risk Science, vol. 4(2), pp.89-100, 2013.

[13] Oktari, R.S. and Kurniawan, H., Framework Ketahanan Puskesmas Dalam Menghadapi Bencana. Jurnal Kedokteran Syiah Kuala, vol. 16 (1), pp.44-52, 2016.

[14] UNISDR. Hyogo framework for action 2005-2015: building the resilience of nations and communities to disasters. Extract from the final report of the World Conference on Disaster Reduction (A/CONF. 206/6), 2005.

[15] J. Carthey, M. R. De Leval, and J. T. Reason, "Institutional resilience in healthcare systems," Quality in health care, vol. 10.1, pp. 29-32, 2001.

[16] S. Fukuma, S. Ahmed, R. Goto, T. S. Inui, R. Atun, and S. Fukuhara, "Fukushima after the Great East Japan Earthquake: lessons for developing responsive and resilient health systems," Journal of global health, vol. 7(1), pp. 010501, 2017.

[17] S. Zhong, M. Clark, X. Y. Hou, Y. Zang, and G. FitzGerald, "Development of key indicators of hospital resilience: a modified Delphi study," Journal of health services research \& policy, vol. 20(2), pp. 74-82, 2015.

[18] World Health Organization. Safe hospitals in emergencies and disasters: structural, non-structural and functional indicators, 2010.

[19] O. M. Yigitbasioglu and O. Velcu, "A Review of Dashboards in Performance Management: Implications for Design and Research," International Journal of Accounting Information Systems, vol. 13(1), pp.41-59, 2012.

[20] D. Arnott and G. Pervan, "A critical analysis of decision support systems research", Journal of Information Technology, vol. 20, pp. 67-87, 2005.

[21] M. O. Ward, G. Grinstein, and D. Keim, "Interactive data visualization: foundations, techniques, and applications," $\mathrm{AK}$ Peters/CRC Press, 2015.

[22] K. Pauwels, T. Ambler, H. C. Bruce, P. Lapointe, D. Reibstein, B. Skiera, B. Wierenga, and T. Wiesel, " Dashboards as a Service: Why, What, How, and What Research Is Needed?," Journal of Service Research, vol. 12 (2), pp. 175-189, 2009.

[23] E. O'Donnell, and J. S. David, "How information systems influence user decisions: a research framework and literature review," International Journal of Accounting Information Systems, no.1, pp.178-203, 2000.

[24] E. B. Goldstein, Sensation and Perception. Thomson Wadsworth, 7th Edition, 2007.

[25] S. Few, Information Dashboard Design, The Effective Visual Communication of Data, O'Reilly Media, Inc, First Edition, 2006.

[26] A. Navarro-Galera, F. J. Alcaraz-Quiles, and D. Ortiz-Rodríguez, "Online dissemination of information on sustainability in regional governments: Effects of technological factors," Government Information Quarterly, vol. 33(1), pp. 53-66, 2016.

[27] R. P. Lourenço, "An analysis of open government portals: A perspective of transparency for accountability," Government Information Quarterly, vol. 32(3), pp. 323-332, 2015.

[28] E. W. Welch, M. K. Feeney, and C. H. Park, "Determinants of data sharing in US city governments," Government Information Quarterly, vol. 33(3), pp. 393-403, 2016.

[29] A. Vetrò, L. Canova, M. Torchiano, C. O. Minotas, R. Iemma, and F. Morando, "Open data quality measurement framework: Definition and application to Open Government Data," Government Information Quarterly, vol. 33(2), pp. 325-337, 2016. 